\title{
Factors that influence the clinical learning experience of nursing students at a Caribbean school of nursing
}

\author{
Juliana Lawal, Steve Weaver, Venise Bryan, Jascinth LM Lindo* \\ School of Nursing, The University of the West Indies, Mona, Jamaica
}

Received: July 3, 2015

Accepted: November 25, $2015 \quad$ Online Published: December 10, 2015

DOI: $10.5430 /$ jnep.v6n4p32

URL: http://dx.doi.org/10.5430/jnep.v6n4p32

\begin{abstract}
Background: Awareness of any issue that may affect the learning process of nursing students in the clinical area is essential to ensure that maximum benefits are gained from this aspect of nursing education. Factors which influenced learning in the clinical area among students at a school of nursing located in urban Jamaica were studied.

Methods: A descriptive cross-sectional study with stratified random sampling of 149 Year 2 and Year 3 students enrolled in a three-year baccalaureate nursing programme was conducted. Data were collected using a 30-item self-administered questionnaire and analysed using SPSS version $17^{\mathrm{R}}$ for Windows ${ }^{\mathrm{R}}$.

Results: All selected participants in Year 3 and $70.3 \%$ of Year 2 recruits, participated in the study; mean age was $23.9 \pm 4.52$ years (range 19-42 years) and $98.4 \%$ were females. The majority of the students, identified preceptorship (89.6\%), support from the clinical staff $(78.4 \%)$, ratio of preceptor to students $(74.8 \%)$ and the quality of pre-clinical conferences $(63.8 \%)$ as having the greatest impact on learning. Over $70 \%$ of students indicated that the type of interpersonal relationships they had with the clinical staff and preceptors affected their learning experiences. Most (75.8\%) of the participants were of the opinion that there were reasons to be anxious in the clinical area.

Conclusions: Positive interpersonal relationships and the use of demonstration and return demonstration were identified as being influential to learning in the clinical area. These factors should inform the teaching of nursing students through preceptorship in the clinical area.
\end{abstract}

Key Words: Nursing students, Learning experience, Clinical area, Clinical staff, Preceptors

\section{INTRODUCTION}

Clinical experience is an important aspect of nursing education as it is the transformation of theoretical knowledge into practice and the cornerstone of nursing as a health profession. ${ }^{[1-4]}$ Effective clinical experience is gained through a supportive clinical environment, which includes the atmosphere of the clinical placement unit, and the relationships shared with clinical staff supervisors and mentors. ${ }^{[5]}$ Based on a quasi-experimental study of 62 Australian students, elements such as good mentoring, relationship with the clinical staff and opportunity to practice were reportedly influential in students' learning in the clinical area. ${ }^{[6]}$ The support given to students by the nursing staff in the clinical setting also plays an important role in the achievement of their learning objectives. ${ }^{[5,7]}$

Nursing students have identified poor interpersonal relationships with clinical staff and preceptors as barriers to learning within the clinical environment. ${ }^{[1,8,9]}$ Negative experiences in the clinical setting often hindered learning and had a greater impact on students' attitudes and confidence than

\footnotetext{
*Correspondence: Jascinth LM Lindo; Email: jaslindo@hotmail.com; Address: School of Nursing, The University of the West Indies, Mona, Jamaica.
} 
positive ones. ${ }^{[9-11]}$ The exposure to intense incivility has led to students' abandonment of their programme of study in some instances. Nurse-educators must therefore ensure that the clinical area is ideal for learning. ${ }^{[12]}$

Nursing students expect a supportive clinical environment that is innovative, creative and highly individualized where they feel they are an integral part of the health team and feel comfortable enough to make mistakes and learn from them. ${ }^{[13,14]}$ Students learn immensely with mentors who appreciate their individuality and the fact that everyone learns differently. ${ }^{[3]}$ It is from clinical placements that students start to garner the necessary attributes of caring, critical thinking skills, application of situational knowledge, competence and clinical skills. Therefore, members of the health team should provide a positive clinical experience to facilitate the progress from novice to expert levels of clinical competence. ${ }^{[15,16]}$

It is vital that students share good relationship with clinical nursing staff as well as their preceptors as this facilitates the identification of the different learning needs and styles of the students. ${ }^{[16,17]}$ Andrews and Roberts ${ }^{[18]}$ argued that the most crucial factor that influences learning in the clinical area is the relationship between the staff and the nursing students. This point was endorsed by Elcigil \& $\operatorname{Sari}^{[19]}$ in a study of nursing students in Turkey. Comparably, a sample of undergraduate nursing students in Australia reported that the unsupportive clinical environment resulted in delay in meeting their clinical training objectives. ${ }^{[20]}$

There are other factors which affect the clinical learning experience of nursing students including the influence of peers although the interpersonal relationship between preceptors and students appear to be the major one. ${ }^{[21]}$ For example, the duties conducted by students will have an effect on their learning experience of their peers. ${ }^{[22]}$ Although this has not been specifically studied research conducted at two nursing schools in Jamaica identified clinical duties as the most common source of stress and this is likely to have a negative effect on learning. ${ }^{[23]}$ In fact, more than half of the final year students who participated in the study experienced two or more symptoms of stress and burnout. ${ }^{[23]}$ Further, another Jamaican study of second year nursing students cited interaction with clinical staff and financial concerns as significant sources of stress. ${ }^{[24]}$ The authors in highlighting the need for additional research suggested that failure to gain insight into the students' learning experience and to implement strategies to address the concerns may result in significant negative consequences for the nursing profession.

The teaching and learning process in the clinical setting is best facilitated through culturally sensitive contextual evidence-based practice. ${ }^{[25,26]}$ Prior to 2002, nursing educa- tion in Jamaica was mostly delivered through 3-year hospitalbased apprenticeship programs. ${ }^{[27]}$ Since 2004 all nursing students are enrolled in university based, 4-year baccalaureate programme in which clinical experience commence in the second year of study. Students complete a total of 2,000 clinical hours as required by the Nursing Council of Jamaica. Clinical preceptorship is provided by faculty based preceptors, supported by registered nurses assigned to the clinical area. Students visit a number of public and semi-private teaching hospitals, community health centres and schools for clinical experience. The number of students assigned to units varies widely and is often dictated by the health institutions.

With the shift from clinical focus to being academically driven, nursing schools need to be vigilant in ensuring that students are still able to effectively meet the clinical objectives and competently bridge the theory/practice gap. ${ }^{[13,28]}$ This paper describes undergraduate nursing student's views regarding factors that influenced their clinical learning experiences. The study also sought student's input in developing strategies for the improvement of clinical learning experience at a Caribbean school of nursing. A number of qualitative studies have been done outside of the Caribbean on this aspect of nursing education as nursing schools have transitioned from the hospital based apprenticeship programs. ${ }^{[29-31]}$ However, there are fewer quantitative studies and none specific to the factors that affect learning in the clinical area in the Caribbean context. Knowledge about the perceived factors that influence learning in nursing students is essential in any student centred learning environment and will assist nurse educators to develop appropriate teaching strategies for the clinical learning environment.

\section{Theoretical framework}

This research was guided by Imogene King's Goal Attainment Theory and conceptual framework of three interacting systems. ${ }^{[32]}$ King's conceptual framework focuses on the relationship between three interacting systems, namely: individual, interpersonal, and social. ${ }^{[33]}$ As such, these factors were considered in the design of the study instrument, data analysis and in the interpretation of the study findings. Interaction, transaction, communication, role, and stress are the concepts that are associated with the interpersonal system. ${ }^{[34]}$ King developed the Goal Attainment Theory from the interpersonal system of the conceptual framework and suggests people meet in organizations, interact with each other, and allow functioning in roles. ${ }^{[35]}$ Humans are open systems, constantly and purposefully interacting with the environment. ${ }^{[34]}$ This assumption by Imogene King is applicable to the clinical setting as nursing preceptors and students are strangers with separate roles in the quest of what should 
be a nurturing positive interpersonal relationship. Both students and preceptors collaborate to set clinical learning goals which are pursued during the course of the semester. ${ }^{[36]}$

\section{MeTHODS}

A cross sectional descriptive study design was used to describe the nursing students' perceptions of the learning experience in the clinical area. A 30-item self-administered questionnaire was used in this quantitative study.

\subsection{Recruitment and sample}

The undergraduate nursing student population in Years 2 and 3 at the urban Jamaica school of nursing was 299. All full time students who had satisfactorily completed a minimum of two clinical rotations (405 hours excluding lab hours) met the inclusion criteria. A sample size of 149 , based on a $5 \%$ margin of error, confidence level of $95 \%$ and a response distribution of 50\% was calculated. The school's register for the students in Years 2 and 3 was used as the sample frame. Students were stratified by year of study and a table of random numbers used to select a proportionate representation of the students (50\% of each stratum). Therefore, the sample was made up of $(n=76 / 152)$ second year students and $(n=$ 73/147) third year students.

\subsection{Data collection and instrumentation}

The 30-item self-administered questionnaire was developed by the researchers as guided by the literature. ${ }^{[27,28,37-39]}$ Nursing students were asked about the factors they felt affected their learning experience in the clinical area. The student's perceptions of an ideal learning environment were also sought using mainly Likert-type with response options ranging from "Strongly Agree" (1), "Agree" (2), "No Opinion" (3), "Disagree" (4) and "Strongly Disagree" (5). Two open-ended items regarding suggestions to improve learning in the clinical area were included. The instrument was reviewed by three clinical and educational specialists and pretested among 20 students not included in the study population resulting in minor modifications to questions relating to the clinical learning experiences of students. A Cronbach alpha score of 0.85 , a high level of internal consistency was recorded by the instrument. Data were collected two days in April 2012, during students' lunch break.

\subsection{Ethical considerations}

Ethical approval was obtained from the institutional review board the study and permission to conduct the study was granted by the administration of the school of nursing. The researchers were not actively involved in teaching the students at the time the study was being conducted and students were reminded of their right to withdraw. The study was explained explicitly to the students and they were reminded that no names or identification numbers were required on the questionnaire. Written informed consent was obtained before the questionnaires were administered. Each completed questionnaire was placed in an envelope provided by the researcher to maintain confidentiality and anonymity. Questionnaires were then stored in a locked filing cabinet.

\subsection{Data analysis}

Data were analysed using the Statistical Package for the Social Sciences (SPSS ${ }^{\circledR}$ ) software for Windows version 17. Demographic characteristics were summarized using descriptive statistics and measures of central tendency. The Pearson correlation coefficient was used to assess the relationship of specific factors and the learning experience of the nursing students in the study. Analysis of the open-ended questions was done by coding and summarizing responses into themes which were then entered into SPSS ${ }^{\circledR}$. The level of significance for the results identified in this study was $p \leq .05$.

\section{RESULTS}

The overall response rate was $85 \%$ with $100 \%$ of Year 3 and $70.3 \%$ of Year 2 students participating. Participants' mean age was $23.9 \pm 4.5$ years (range 19 to 42 years). The majority of participants were females (98.4\%), 25 years old or younger (67.7\%), and single (83.5\%). Second year students reported fewer $(3.44 \pm 1.15)$ mean number of clinical rotations in the last academic year than did third year students $(4.88 \pm 1.74, t=-5.12 ; p=.0001)$ (see Table 1). Participants indicated that prior to clinical placement they expected to meet: supportive nursing staff (95.9\%); a student-friendly environment (89.6\%); opportunity to care for real patients (87.7\%); application of theory to practice $(85.4 \%)$ and available resources $(84.4 \%)$. The response of participants did not differ by year of program.

More than $90 \%$ of the participants agreed that support from clinical staff and post clinical conferences influenced their learning. A similar percentage rated demonstration as the best teaching method to use in the clinical area. This was followed by observation from Year 2 students $(84.9 \%)$ and Year 3 students (81.9\%). On the other hand, only $27.9 \%$ of students $19-25$ years and $33.3 \%$ of those $26-42$ years felt that lectures were effective in the clinical area. Of note, the majority of the participants $(96.1 \%)$ agreed that they learned best when a return demonstration was facilitated in the clinical area (see Figure 1).

\section{Factors affecting learning in the clinical area}

Overall $74.8 \%(n=125)$ of students felt that the number of students assigned to preceptors and pre-clinical conferences 
influenced their learning and there was no difference between the responses of the younger and older age groups $\left(\chi^{2}=1.89\right.$, $i=.757)$. There was significant association between quality of the relationships shared with clinical staff and learning among nursing students; however, this relationship was weak $(r=0.003 ; p \leq .01)$. Regarding influence of clinical staff on learning, $78.8 \%$ of Year 2 students and $73.3 \%$ of Year 3 students agreed that the relationship with the clinical staff influenced learning, while a higher proportion $(80.7 \%)$ of the 2 nd year compared to $(63.5 \%)$ of the 3 rd year students agreed that preceptors influenced their learning $(r<.001 ; p$ $\leq .01)$.

While most of the students felt there were reasons to be anxious in the clinical area, this was not significantly different between younger $(77.9 \%)$ and older $(69.7 \%)$ students. This variable did not differ statistically between year groups as $77.6 \%$ of Year 2 and $74.7 \%$ of Year 3 participants agreed there were reasons to be anxious (see Table 2).
Table 1. Demographic characteristics of respondents

\begin{tabular}{lll}
\hline Demographic Characteristics & $\mathbf{n}$ & $\mathbf{\%}$ \\
\hline Age group & & \\
$19-25$ & 86 & 67.7 \\
$26-42$ & 33 & 26 \\
Gender & & \\
$\quad$ Male & 2 & 1.6 \\
$\quad$ Female & 125 & 98.4 \\
Current Union status & & \\
$\quad$ Single & 106 & 83.5 \\
$\quad$ Committed & 21 & 16.5 \\
$\quad$ Year in program & & \\
$\quad$ Year 2 & 52 & 70.3 \\
$\quad$ Year 3 & 75 & 100 \\
Mean Number of Clinical Rotations & & \\
completed in the last academic year $*$ & & \\
$\quad$ Year 2 & 50 & $3.44 \pm 1.146$ \\
$\quad$ Year 3 & 75 & $4.88 \pm 1.740$ \\
\hline * p $<0001$ & & \\
&
\end{tabular}

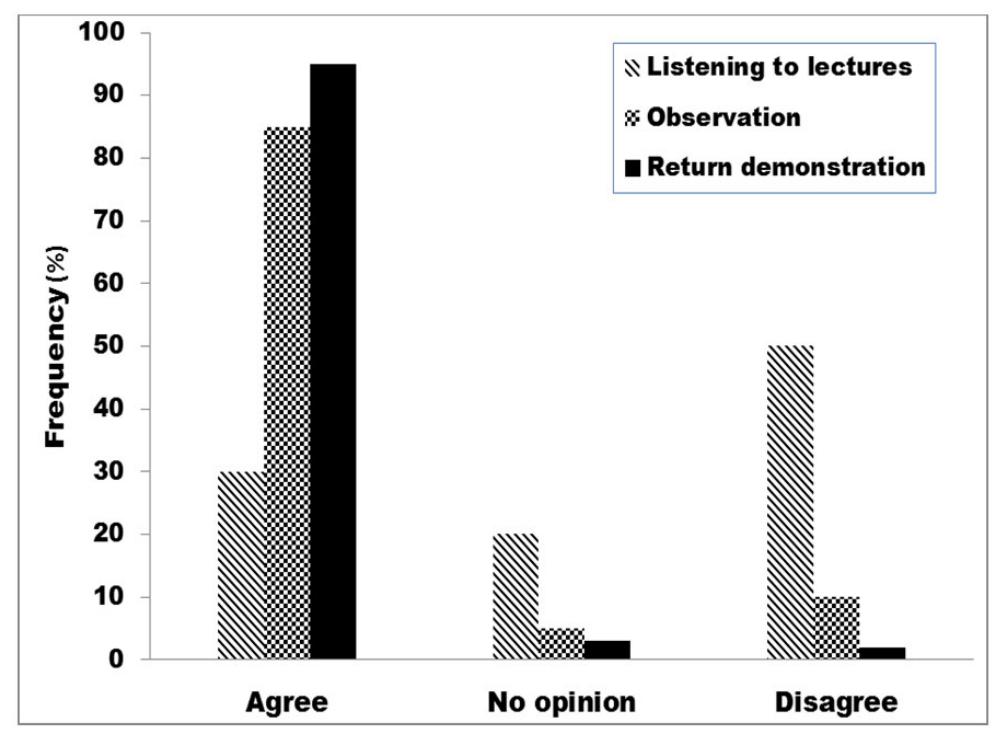

Figure 1. Factors that influence the learning experience of nursing students in the clinical area at an urban school of nursing in Jamaica

Table 2. Responses (\%) of agreement to influencing factors on learning by year of study

\begin{tabular}{llll}
\hline Factors & 2nd Year of study & 3rd Year of study & \multirow{2}{*}{ Significance } \\
\hline Influence of clinical staff on learning & 78 & 73.3 & $\mathrm{~ns}$ \\
Preceptors/student ratio Influenced learning & 80.7 & 63.5 & $p \leq .01$ \\
There were reasons to be anxious in clinical & 77.6 & 74.7 & $\mathrm{~ns}$ \\
\hline
\end{tabular}

The quality of preceptorship (90\%), staff in the clinical areas (78.4\%), followed by opportunities to learn $(73.8 \%)$ were cited by the participants $(n=112)$ as areas in the clinical environment that needed improvement (see Figure 2). Fewer respondents indicated that collaboration between schools and clinical area and student-patient ratio were areas needed to 
be improved (68\% and 50\%, respectively). Finally, $60 \%$ of the clinical area were in need of improvement. the participants indicated that the teaching methods used in

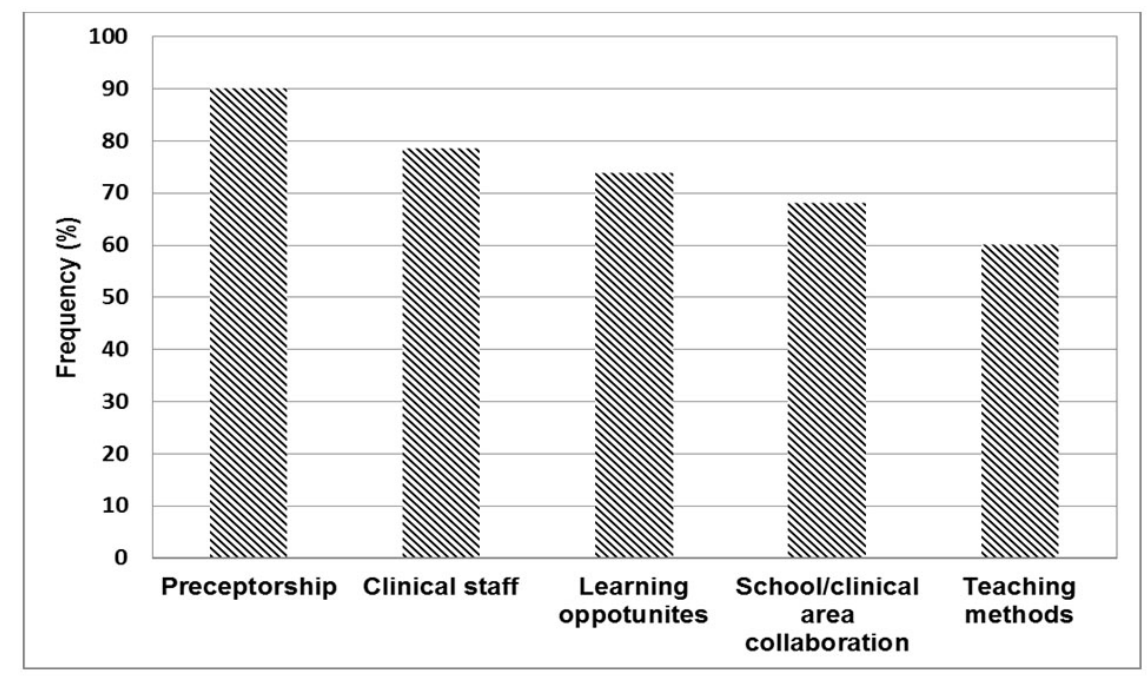

Figure 2. Areas suggested as needing improvement

\section{Discussion}

In the current study, the majority of the nursing students felt that support from the clinical staff and faculty had an impact on their learning as previously reported in other studies. ${ }^{[40-42]}$ Support from nursing staff in the clinical area can be a source of motivation to nursing students as they feel welcome and a part of the team, thereby helping them with learning. ${ }^{[16,17,30]}$ Clinical staff and educators need to recognize that students thrive in an environment where they feel respected and a part of the team as anxiety levels of nursing students increased in the presence of unsupportive clinical environments and inhibited learning. ${ }^{[43]}$ Supportive environments facilitate a process of socialization where anxiety lessens, confidence increases and learning is enhanced. ${ }^{[13]}$ In fact, participants expected to meet supportive clinical staff and a student-friendly environment. They also expected to have the opportunity to care for real patients, application of theory to practice and available resources in the clinical area.

Less than half of the participants found their clinical areas to be friendly and they identified the needed for improvement in all areas studied as was reported from previous studies. ${ }^{[5,44]}$ Despite these results, majority of the participants believed that the clinical area was supportive of learning. The relationship between staff and the nursing students is one of the most influential factors for students leaning in the clinical area. ${ }^{[1,16,18]}$ This has been attributed to the fact that clinical staff plays the role of counsellor, coach, mentor and more to the nursing students as they transition from novice to experts in the field of nursing. ${ }^{[45]}$ Nursing students in the study setting have also suggested that the quality of the relationship with assigned independent preceptors also influenced their learning and identified characteristics such as "dedicated and approachable" as being paramount for improved learning experience. $^{[41]}$

Greater than $70 \%$ of the students studied felt there was a need to improve opportunities for learning in the clinical area. The lack of learning opportunities have been noted in other settings as students expressed the need for more time to complete procedures correctly without worrying about time urgencies. ${ }^{[5]}$ Failure to provide adequate learning opportunities for students to competently and safely care for patients could result in a nursing graduate who has not met the required standards and competences of the profession. ${ }^{[46]}$ This lack of opportunity to develop required competencies could adversely affect the nursing students' learning and eventual the care rendered to patients. ${ }^{[13]}$ In the context of a large number of nursing students and limited clinical space in the Jamaican setting; the findings of the current study indicate a need for improvement of nursing students' clinical learning experience. Further, there are many challenges with preceptorship such as in the context of the current study where full-time staff nurses are required to teach skills to students on the wards. This is in the face of a severe nursing shortage in the Caribbean due to migration of nurses to North America and elsewhere in the developed world seeking better wages and opportunities. ${ }^{[4]}$ Lofmark and Wikblad ${ }^{[48]}$ in examining clinical practice in Sweden, identified lack of opportunity for the nursing students to practice in the clinical area as a problem; suggesting that lack of opportunity for the nursing students to practice affects the conversion of the theoretical 
knowledge to practice. ${ }^{[38]}$ The aim of clinical experience is to allow nursing students to learn how to apply principles and theories learnt in class in the clinical setting. Ultimately, the quality of clinical experience and resultant expertise affects the nurse's level of competence. ${ }^{[45,46]}$

Like the findings of Bryan et al., the students studied, also identified anxiety as an influential factor that impacted learning in the clinical area, supporting the earlier work done in Jamaica. ${ }^{[41]}$ Bryan and colleagues' descriptive study of 192 students enrolled in Year 1 to Year 3 of a baccalaureate nursing degree programme concluded that, as students progressed through the program they required less support from educators. ${ }^{[41]}$ In addition, the anxiety experienced at the initial stage of clinical placement may be from having to adapt to a new ward/unit, having to learn the culture of the unit and having to care for real patients. Moreover, high levels of anxiety during the initial clinical experience associated with the fear of making mistakes and unapproachable clinical staff have been reported in other settings..$^{[1,9,44]}$ The quality of interpersonal relationships in the clinical setting can affect patient safety; especially for first placement students, ${ }^{[1]}$ as would be the case in this current study for year two students who reported increased anxiety levels.

The vast majority of the participants studied, indicated that they learned best through return demonstrations. This finding was comparable to students in Italy who reported they learnt best when demonstrations and return demonstrations were used while being supervised by the nurse or preceptor. Students also preferred when learning from experience while being guided; reflective of a tutoring model. ${ }^{[49]}$ The importance of using teaching methods that learners prefer in order to accelerate the transfer of knowledge have been previously. ${ }^{[50]}$ The use of appropriate teaching methods should be explored in the study population given the ultimate goal of clinical placement is the enhanced transfer of theory to practice among students.

The participants in this study indicated that post-clinical conferences were essential to their learning. Like the current study population, Australian undergraduate nursing students were desirous of more opportunities for debriefing and group discussion post clinical experiences. ${ }^{[25]}$ This was likely to contribute to the facilitation of feedback on their perfor-

\section{REFERENCES}

[1] Killam LA, Heerschap C. Challenges to student learning in the clinical setting: A qualitative descriptive study. Nurse Education Today. 2013; 33(6): 684-691. PMid:23141689 http://dx.doi.org/10. $1016 / j$.nedt. 2012.10 .008

[2] Heath P. Australian Department of Education, Science and Training. mances. ${ }^{[48]}$ According to Carolan-Olah and Kruger getting feedback on performance served to identify areas of strengths and weaknesses which provided students with guidance for future clinical learning. ${ }^{[25]}$ Another factor found to affect the learning of the nursing students is the lack of collegial support. ${ }^{[51]}$ Over $50 \%$ of the study participants indicated that there was a need for improvement in the relationship between the school and clinical units, however, no reasons were offered by the group. Strong collaborative partnerships with effective communication between the nursing schools and health care institutions are critical to successful clinical experiences. ${ }^{[30,52,53]}$

\section{Limitations}

Although the study was conducted at a single school; this is the oldest and largest school of nursing in the Caribbean and over see's five smaller undergraduate programmes from across the country and two schools from the region. Findings are therefore at minimum reflective of the issue at hand and appears congruent with global findings. Despite the high crochbach alpha yeilded by the instrument used in this descriptive study, it is note worthy that the questionnaire was developed by the researchers and therefore does not provide a history of its relibility.

\section{Conclusion}

Study participants outlined multiple factors which were deemed influential to learning in the clinical area with demonstration being identified as the most favoured teaching method. The findings of this study underscores the importance of effective interpersonal relationship between clinical staff and nursing students in creating a positive learning environment. It is imperative that nursing educators explore the factors identified with a goal to determine strategies to improve learning and transfer of theory to practice in the clinical areas. The clinical staff should be prepared in their role of helping in the socialization of nursing students in the clinical area, as they are teaching students to care. Student nurses who are exposed to a caring attitude and evironment are far more likely to reflect these characteristics when they become registered nurses.

\section{CONFLicts OF INTEREST Disclosure}

The authors declare that there is no conflict of interest.
National review of nursing education 2002 our duty of care. 2002. Available from: http://www.nnnet.gov.au/downloads/n3et_ final_report.pdf

[3] Lambert V, Glecken M. Clinical education facilitators: A literature review. Issues in Clinical Nursing. 2005; 14: 664-673. PMid:15946274 http://dx.doi.org/10.1111/j.1365-2702.2005.01136.x 
[4] Rodriguez TJ. Understanding human behavior. Manila, Philippines: Rex Book Store, Inc.; 2009. 56 p.

[5] Chaun OL, Barnett T. Student, tutor and staff nurse perceptions of the clinical learning environment. Nurse Education in Practice. 2012; 12(4): 192-197. PMid:22277167 http://dx.doi.org/10.1016 /j.nepr.2012.01.003

[6] Henderson A, Twentyman M, Eaton E, et al. Enhancing support for nursing students in the clinical. Nursing Times. 2010; 102(14): 35.

[7] Nash R, Lemcke P, Sacre S. Enhancing transition: An enhanced model of clinical placement for final year nursing students. Nurse Education Today. 2009; 29: 48-56. PMid:18692279 http://dx.d oi.org/10.1016/j.nedt.2008.06.004

[8] Melincavage SM. Student nurses' experiences of anxiety in the clinical setting. Nurse Education Today. 2011; 31(8): 785 789. PMid:21641701 http://dx.doi.org/10.1016/j.nedt. 20 11.05 .007

[9] Shabana IA, Khater WA, Akhu-Zaheya LM. Undergraduate nursing students' stress sources and coping behaviours during their initial period of clinical training: A Jordanian perspective. Nurse Education in Practice. 2012; 12(4): 204-209. PMid:22281123 http: //dx.doi.org/10.1016/j.nepr.2012.01.005

[10] Algoso M, Peters K. The experiences of undergraduate assistants in nursing. Nurse Education Today. 2012; 32(3): 192 202. PMid:21875766 http://dx.doi.org/10.1016/j.nedt. 20 11.08 .002

[11] Anthony M, Yastik J. Nursing students experiences with incivility in clinical education. Journal of Nursing Education. 2011; 50(3): 140-144. PMid:21323254 http://dx.doi.org/10.3928/01484 834-20110131-04

[12] Levett-Jones T, Lathlean J, Higgins I, et al. Staff-student relationships and their impact on nursing students' belongingness and learning. Journal of Advanced Nursing. 2009; 65(2): 316324. PMid:19191935 http://dx.doi.org/10.1111/j.1365-2 $648.2008 .04865 . x$

[13] Papastavrou E, Lambrinou E, Tsangari H, et al. Student nurses experience of learning in the clinical environment. Nurse Education in Practice. 2010; 10(3): 176-182. PMid:19700368 http: //dx.doi.org/10.1016/j.nepr.2009.07.003

[14] Papathanasiou IV, Konstantinos T, Pavlos S. Views and perceptions of nursing students on their clinical learning environment: Teaching and learning. Nurse Education Today. 2014; 34(1): $57-$ 60. PMid:23481172 http://dx.doi.org/10.1016/j.nedt. 20 13.02.007

[15] Midgley K. Pre-registration student nurses perception of the hospital learning environment during clinical placements. Nurse Education Today. 2006; 26: 338-345. PMid:16406618 http://dx.doi.org /10.1016/j.nedt. 2005.10.015

[16] Murphy F, Rosser M, Bevan R, et al. Nursing students' experiences and preferences regarding hospital and community placements. Nurse Education in Practice. 2012; 12(2012): 170-175. PMid:22265991 http://dx.doi.org/10.1016/j.nepr.2011.12.007

[17] Kelly C. Student's perceptions of effective clinical teaching revisited. Nurse Education Today. 2007; 27(8): 885-892. PMid:17321013 http://dx.doi.org/10.1016/j.nedt.2006.12.005

[18] Andrews M, Roberts D. Supporting student nurses learning in and through clinical practice: The role of the clinical guide. Nurse Education Today. 2003; 23(7): 474-481. http://dx.doi .org/10.10 16/S0260-6917(03)00076-5

[19] Elcigil A, Sari HY. Facilitating Factors in Clinical Education in Nursing. Nursing Clinical Education. 2011; 4(2): 67-71.

[20] Chan DS. Nursing students' perceptions of hospital learning environments-an Australian perspective. International Journal of Nurs- ing Education Scholarship. 2004; 1(1): 4. PMid:16646895 http: //dx.doi.org/10.2202/1548-923X.1002

[21] Bryan VD, Lindo J, Anderson-Johnson P, et al. Using Carl Rogers' Person-Centered Model to Explain Interpersonal Relationships at a School of Nursing. Journal of Professional Nursing. 2015; 31(2): 141-148. PMid:25839954 http://dx.doi.org/10.1016/j.pro fnurs.2014.07.003

[22] Chan DS. Validation of the clinical learning environment inventory. Western Journal of Nursing Research. 2003; 25(5): 519-532. http: //dx.doi.org/10.1177/0193945903253161

[23] Llewellyn-Johnson S, Lopez S, Lindo JLM, et al. Stress and burnout experienced by $\mathrm{BScN}$ final year nursing students in Jamaica. West Indian Medical Journal. 2011; (Suppl. 4): 60.

[24] McBean-Graham M, Lindo JLM, Kahwa E. Factors associated with stress in the clinical settings among second year student nurses from two schools in Jamaica. West Indian Medical Journal. 2012; (Suppl. 6): 61 .

[25] Carolan-Olah M, Kruger G. Final year students' learning experiences of the bachelor of midwifery course. Midwifery. 2013. http://dx.doi.org/10.1016/j.midw.2013.07.010

[26] Tulbure C. Do different learning styles require differentiated teaching strategies? Procedia - Social and Behavioral Sciences. 2011; 11: 155159. http://dx.doi.org/10.1016/j.sbspro. 2011.01 .052

[27] Hill K. Shot in arm for nursing-Lee Chin donates $\$ 155 \mathrm{~m}$ to Northern Caribbean University (NCU). [cited 2006 October]. Available from: http://jamaica-gleaner.com/gleaner/20060908/le ad/lead1.html

[28] Löfmark A, Thorkildsen K, Råholm M, et al. Nursing students' satisfaction with supervision from preceptors and teachers during clinical practice. Nurse Education in Practice. 2012; 12(3): 164-169. PMid:22225731 http://dx.doi.org/10.1016/j.nepr.2011.12.005

[29] Dunn SV, Hansford B. Undergraduate nursing students' perception of their clinical learning environment. Journal of Advanced Nursing. 1997; 25: 1299-1306. PMid:9181430 http://dx.doi.org/10.10 46/j.1365-2648.1997.19970251299.x

[30] Papp I, Markkanen M, Von-Bonsdorff M. Clinical environment as learning environment: student nurses' perceptions concerning clinical learning experiences. Nurse Education Today. 2003; 23 (4): 262-268. http://dx.doi.org/10.1016/S0260-6917(02)00185-5

[31] Croxon L, Maginnis C. Evaluation of teaching models for nursing practice. Nurse Education in Practice. 2009; 9 (4): 236243. PMid:18722161 http://dx.doi.org/10.1016/j.nepr. 20 08.06 .004

[32] Kozier B, Erb G, Berman S, et al. Fundamentals of nursing (9th ed.). UpperSaddle, NJ: Prentice Hall; 2011. 52 p.

[33] Williams L. Imogene King's Interacting Systems Theory-application in emergency and rural nursing. Online Journal of Rural Nursing \& Health Care. 2001; 2(1): 25-30.

[34] Bogard P. Synopsis of King's theory of goal attainment. 2007.

[35] King IM. A theory for nursing: Systems, concepts, process. New York, USA: Wiley; 1981.

[36] King IM. King's theory of goal attainment in practice. Nursing Science Quarterly. 1997; 10(4): 180-185. http://dx.doi.org/10. $1177 / 089431849701000411$

[37] Chan D. Development of an innovative tool to assess hospital learning environments. Nurse Education Today. 2001; 21(8): 624631. PMid:11884175 http://dx.doi.org/10.1054/nedt. 2001 .0595

[38] Chan D. Development of the clinical learning environment inventory: Using the theoretical framework of learning environment studies as a tool to assess preregistration nursing students' perceptions of the 
hospital as a learning environment. Journal of Nursing Education. 2002; 41(2): 69-75. PMid:11852986

[39] Saarikoski M, Isoaho H, Warne T, et al. The nurse teacher in clinical practice: developing the new subdimension to the Clinical Learning Environment and Supervision (CLES) Scale. International Journal of Nursing Studies. 2008; 45(8): 1233-1237. PMid:17803996 http://dx.doi.org/10.1016/j.ijnurstu.2007.07.009

[40] Stanhope M, Lancaster J. Foundations of nursing in the community: Community-oriented practice. St. Louis: Mosby Elsevier; 2005.

[41] Bryan V, Weaver S, Anderson-Johnson P, et al. The effect of interpersonal relationships between nursing students and lecturers on learning outcomes at a Jamaican nursing school. Caribbean Journal of Nursing. 2013; 1(1): 41-48.

[42] Yanez F, Sanchez R, Giribet M, et al. The learning and satisfaction of nursing students during clinical practice. Enfermeria Clinica. 1997; 7(1): 16-24.

[43] Del Prato D, Bankert E, Grust P, et al. Transforming nursing education: A review of stressors and strategies that support students' professional socialization. Advances in Medical Education and Practice. 2011; 2: 109-116. PMid:23745082 http://dx. doi .org/10. 2147/AMEP. S18359

[44] Brown L, Herd K, Humphries G, et al. The role of the lecturer in practice placements: What do students think? Nurse Education in Practice. 2005; 5(2): 84-90. PMid:19038184 http://dx.doi .org /10.1016/j.nepr.2004.03.006

[45] Billings DM, Halstead JA. Teaching in nursing: A guide for faculty (2nd ed.). Philadelphia, PA: Saunders; 2004.

[46] McHugh MD, Lake ET. Understanding Clinical Expertise: Nurse Education, Experience, and the Hospital Context. Research in Nursing \& Health. 2010; 33(4): 276-287. PMid:20645420 http://dx.doi . org/10.1002/nur. 20388
[47] World Bank. The nurse labor \& education markets in the English-speaking CARICOM: Issues and options for reform (48988-LAC). 2009. Available from: http://siteresources. worldbank. org/INTJAMAICA/R esources/The_Nurse_Labor_Education_Market_Eng.pdf

[48] Lofmark A, Wikblad K. Facilitating and obstructing factors for development of learning in clinical practice: A student perspective. Journal of Advanced Nursing. 2002; 34(1): 43-50. http: //dx.doi.org/10.1046/j.1365-2648.2001.3411739.x

[49] Brugnolli A, Perli S, Viviani D, et al. Nursing students' perceptions of tutorial strategies during clinical learning instruction: A descriptive study. Nurse Education Today. 2011; 31(12): 152156. PMid:20826043 http://dx.doi .org/10.1016/j.nedt. 20 10.05 .008

[50] Billett $\mathrm{S}$, Newton JM, Jolly B, et al. Lost in translation: barriers to learning in health professional clinical education. Learning in Health and Social Care. 2009; 8(4): 315-327. http://dx.doi.org/10. $1111 / j .1473-6861.2009 .00229 . x$

[51] Atkins S, Williams A. Registered nurses' experiences of mentoring undergraduate students. Journal of Advanced Nursing. 1995; 21(5): 1006-1015. PMid:7601984 http://dx.doi.org/10.1046 $/ j .1365-2648.1995 .21051006 . x$

[52] Decker J, Shellenbarger T. Strategies for nursing faculty to promote a healthy work environment for nursing students. Teaching and Learning in Nursing. 2012; 7(2): 56-61. http://dx.doi.org/10.1016 /j.teln.2010.12.001

[53] Gidman J, McIntosh A, Melling K, et al. Student perceptions of support in practice. Nurse Education in Practice. 2011; 11(6): 351 355. PMid:21458375 http://dx.doi .org/10.1016/j.nepr. 20 11.03 .005 